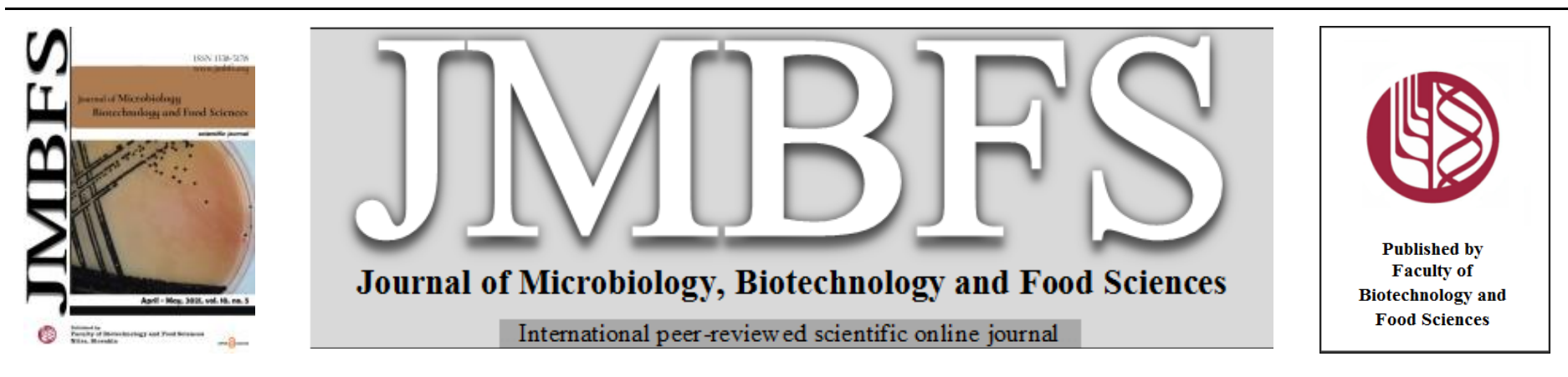

\title{
STUDYING THE EFFECT OF CHITOSAN ON BACILLUS CEREUS PRODUCING CEREULIDE TOXIN IN MILK AND SOME DAIRY DESSERTS
}

\author{
Walaa M. ElSherif $*^{l}$, Abeer H. M. El Hendy ${ }^{2}$, Neveen A. Elnisr ${ }^{2}$ and Nahed M. Wahba ${ }^{l}$ \\ Address(es): \\ ${ }^{1}$ Food Hygiene Department, Animal Health Research Institute, Agriculture Research Center, Egypt,7771, Assiut city,01061605667. \\ ${ }_{2}^{2}$ Pathology Department, Animal Health Research Institute, Agriculture Research Center, Egypt, 7771, Assiut city.
}

*Corresponding author: me.elsherif@yahoo.com

https://doi.org/10.15414/jmbfs.3417

\section{ARTICLE INFO}

Received 9. 7. 2020

Revised 9. 12. 2020

Accepted 17. 12. 2020

Published 1. 4. 2021

Regular article OPEN $\partial$ ACCESS

\begin{abstract}
A total of 150 samples of raw milk and two types of refrigerated processed dairy desserts dishes (cooked rice with milk and Mehalabia dishes) (50 for each) were collected from dairy shops and local restaurants in Assuit City, Egypt. ISO7932 method was used for enumeration of B. cereus, afterwards a PCR was performed to confirm the presence of cereulide toxin (ces) gene. In addition, the effect of different concentrations of chitosan and chitosan nanoparticles (CNPs) $(0.05,1 \%)$ on B. cereus was studied in pasteurized milk.The shelf life was evaluated by clot on boiling test and $\mathrm{Ph}$ value. Their pathological effect was detected by orally administration to experimental rats to investigate their adverse effect on rats liver and intestine using histopathological examination. The most prominent potent bactericidal effect was observed inCNPs $1 \%$, B. cereus count reached to undetectable level at 5 th day of refrigerated storage. The pasteurized milk inoculated with B. cereus, chitosan and CNPs showed some pathological lesions in rats treated with B. cereus, while the chitosan $0.5 \%$ had antibacterial activities without cytotoxic effect on rat tissues, alternatively to CNPs $1 \%$, which exist edematous tips of intestinal villi and mild kupffer cells activation in liver.Therefore, our results contribute data that are primary to indicate the risk of food poisoning due to B. cereus and trials to control that in food by careful using of nanotechnology. However, the additional researches are needed to safe using of this technology even on natural nano-materials as it at nano-size gain new qualities.
\end{abstract}

Keywords: Rice, Nanoparticles, Histo-Pathology, Mehalabia, Rat, Liver toxicity

\section{INTRODUCTION}

B. cereus is a spore forming opportunistic environmental wide spread pathogen, cause food-borne outbreaks in human (Yu et al., 2019). Zhao et al. (2020) had isolated $B$. cereus from different dairy products, and considered it as a potential risk pathogen need to contribute an effective prevention and control program. In addition, several publications reported an increasing number of foodborne intoxication cases caused by B.cereus.For instance, European Union about 600 700 annually reported confirmed cases of foodborne outbreaks linked to $B$. cereus toxins (Messelhäußer and Ehling-Schulz, 2018). Bacillus cereus strains have shown to produce seven different toxins (Papan et al., 2019), the most dangerous one is cereulide toxin, which performed in food. This toxin is a small cyclic dodecadepsipeptide encoded by the ces gene. The cereulide is heat and $\mathrm{pH}$ stable, highly resistant to protease activity and it remains active through the gastro-intestinal passage but, due to the lack of a suitable assay, it considered the least well known (Ceuppens et al., 2012; Zhang et al., 2015). The toxin produced in food during vegetative growth, and after the toxin produced, no treatment can destroy this stable molecule, including proteolysis and extreme $\mathrm{pH}$ (Chica et al., 2019).

Generally, food matrices rich in carbohydrates, such as pasta and rice, as well as milk and dairy products have the highest risk of causing cereulide intoxications (Papan et al., 2019). Outbreaks of B. cereus foodborne illness associated with consumption of cooked rice have been reported worldwide (Kumari and Sarkar, 2014; Yang et al., 2017; Alvarenga et al., 2018).

Chitosan is a modified natural carbohydrate polymer prepared by the partial $\mathrm{N}$ deacetylation of chitin, a natural biopolymer derived from crustacean shells such as crabs, shrimps and lobsters. The antimicrobial activity of chitosan depends on the degree of deacetylation and a molecular weight (Tantala et al.,2012) Chitosan is safe, non-toxic and can interact with polyanions to form complexes and gels (Sukmark et al., 2011). It has many antibacterial mechanisms activity, as intercellular leakage hypothesis is widely accepted (Silalahi $\boldsymbol{e t}$ al., 2016), blockage of nutrient flow by forming a polymer layer around bacterial cells (Fernandes et al., 2009). In addition, it may affect the structure of the phospholipid bilayer in the cell membrane resulting in the release of some of the cellular components (Yusman, 2006; Dutta and Dutta, 2011). Because chitosan has many advantages properties and mostly safe, so it used in nanotechnology as chitosan nanoparticles (CNPs) depend on ionic gelation method, which describes the crosslinking reaction of chitosan with sodium tripolyphosphate (TPP) (Nguyen et al., 2017; Sreekumar et al., 2018)

Therefore, the objective of our study was to detect the incidence and count of $B$. cereus in raw milk and two dairy desserts then detect the cerulide producing toxin (ces gene) in isolates by using PCR. Another purpose was to investigate the potential of applying chitosan and its nanoparticles as a natural food preservative to control the growth of B. cereus in pasteurized milk during storage. In addition, to provide a histopathological evaluation for the antimicrobial activity of chitosan and CNPs in different concentrations against B. cereus on intestine and liver of experimental rats.

\section{MATERIAL AND METHODS}

The prevalence of emetic B. cereus strains in some food samples

Collection of samples

A total of 150 raw milk, cooked rice with milk and Mehalabia dishes samples (50 samples each) were collected from dairy shops of different localities in Assiut city, Egypt and brought to the laboratory by means of refrigerated transport within a timeframe of $\max 2 \mathrm{~h}$. There, all samples were prepared according to APHA (1998).

\section{Identification and Enumeration of $\boldsymbol{B}$. cereus strains}

Enumeration of B. cereus is performed by using ISO7932:2004 method, where the samples were plated on mannitol egg yolk phenol red polymyxin (MEYP, Oxoid, Hampshire, UK) medium and then incubated for $24-48 \mathrm{~h}$ at $30^{\circ} \mathrm{C}$ (Tallent et al., 2012). The presumptive cultures of B. cereus were inoculated on Kim and Goepfert medium with polymyxin B as the selective agent and permit presumptive identification by the lecithinase reaction on the egg yolk and the 
inability of $B$. cereus to catabolize mannitol (Kim and Goepfert, 1971). Motility, endospore formation, followed by species confirmation using biochemical tests as described by Kim et al. (2011).

\section{Identification of ces gene of $B$. cereus by PCR}

This part was done at Biotechnology Unit, Animal Health Research Institute, Giza, Egypt.

Genomic DNA was obtained using the QIAamp Bacterial DNA Kit (Qiagen, Germany, $\mathrm{GmbH}$ ) following the manufacturer'sspecifications. Polymerase chain reaction (PCR) amplificationwas conducted to detect the cereulide synthetase gene (ces) with a $20 \mathrm{ml}$ reaction mixture consisting of $50 \mathrm{ng}$ genomic DNA, 12.5 $\mathrm{ml}$ PCR Premix TaqTM (Takara, Japan), and $2 \mathrm{mMof}$ each primer according to Ehling-Schulz et al., 2006. The primers used in this study are F. GGTGACACATTATCATATAAGGTG\&

TAAGCGAACCTGTCTGTAACAACA. Primers were supplied from Metabion (Germany).

The antibacterial activity of chitosan and CNPs to inhibit the growth of $B$. cereus

\section{Preparation of chitosan solution}

Different concentrations of chitosan solutions were prepared by dissolving $(0.5$ and $1 \% \mathrm{w} / \mathrm{v}$ ) chitosan in $1 \%$ aqueous acetic acid solution. The solution was stirred at room temperature for $3 \mathrm{~h}$. for complete dispersion of chitosan, Then filtrated through a Whatman No. 3 filter paper. The resultant filtrate solution referred to chitosan solution (Ojagh et al., 2010).

\section{Preparation of CNPs}

The Nanoparticles were prepared following the procedure described by Calvo et al. (1997) and characterized by HRTEMModel JEOLJEM-100CX II in the Electron Microscopy Unit, Assiut University, Egypt. Briefly: a $2.5 \mathrm{mg} / \mathrm{mL}$ chitosan solution was prepared by dissolving chitosan in a $0.05 \%(\mathrm{v} / \mathrm{v})$ acetic acid solution and leaving it under stirring for $24 \mathrm{~h}$. The $\mathrm{pH}$ was adjusted to 5.5 with a $0.5 \mathrm{M}$ sodium hydroxide solution and diluted in deionized water to the final desired concentrations. Sodium Tripolyphosphate (TPP) was dissolved in deionized water to a final concentration of $0.25 \mathrm{mg} / \mathrm{mL}$. Then, the TPP solution was added to the chitosan solution drop wise $(0.3 \mathrm{~mL} / \mathrm{min})$ at different TPP chitosan ratios under vigorous magnetic stirring at room temperature. The resulting suspension was then left to jellify for $30 \mathrm{~min}$.

\section{Bacterial suspension inoculation}

The isolated strains were inoculated into Muller Hinton broth and incubated to the growth phase at $37{ }^{\circ} \mathrm{C}$. The growth density was adjusted to match a MacFarland 0.5 standard $\left(8 \log _{10} \mathrm{CFU} / \mathrm{ml}\right)$ according to Yu et al., (2019).

\section{Antimicrobial properties of chitosan and CNPs}

Five replicates of pasteurized milk samples were used for the antibacterial activity. Pasteurized milk samples were purchased from a retail market and examined by phosphatase test to confirm the efficacy of pasteurization (Sharma and Rajput, 2014) Four treatments of chitosan and CNPs at two different concentrations $(0.5$ and $1 \%)$ were used in the experiments, two controls, inoculated (control positive) and none inoculated with B. cereus (contro negative), were tested. All samples were stored at refrigerator temperature $(4 \pm 1$ ${ }^{\circ} \mathrm{C}$ ) and examined every 2 days until the end of the experiment. Freshness pasteurized milk in all control and treated samples were examined using Clot on Boiling test and $\mathrm{pH}$ value was determined by $\mathrm{pH}$ meter.

\section{Sensory evaluation}

Control Pasteurized milk jars (free from the previous prepared B.cereus suspension but inoculated only with chitosan and chitosan nanoparticles at concentrations of 0.5 and $1 \%$, respectively) were prepared as previously mentioned and each was subjected to the previous treatments. Thirty consumers were selected in tearms of different ages, sex (15 females and 15 males) and qualification to the trials. The perception of consumers toward samples with various conc. of chitosan was studied with respect to different attributes (flavor, color and Consistency), in addition to their resultant expressed in overall acceptability (OAA). The level of agreement was scored as strongly agreed (SA), agreed (A), disagreed (D), and strongly disagreed (SD) according to (Nelson and Torut, 1981)

\section{Animals and experimental design}

The experimental procedure was approved by the Ethics Committee of the animals to the Faculty of Veterinary Medicine, Assiut University. Fifty female,

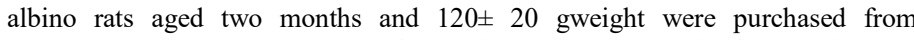
laboratory animal house, Faculty of Medicine, Assiut University for experimenta studies. Rats were kept under laboratory conditions of $65 \%$ humidity, $24-26^{\circ} \mathrm{C}$ and daily light/dark cycle, fed on balanced standard pellets and water was available. Animals allowed 7 days for acclimatization before starting the experiment.

\section{Antimicrobial properties of chitosan and CNPs on experimental rats animals}

The rats were divided into 10 experimental groups (5 animals each) as following: Group 1 (control negative) rats take milk without any treatment. Group 2 (control positive) rats take milk inoculated with $B$. cereus $8 \log _{10} \mathrm{CFU} / \mathrm{ml}$. Group 3 and 4 rats take milk with chitosan 0.5 and $1 \%$, respectively. Groups 5 and 6 rats take milk with CNPs 0.5 and $1 \%$, respectively. Group 7 and 8 rats take milk inoculated with $B$. Cereus $8 \log _{10} \mathrm{CFU} / \mathrm{mland}$ chitosan 0.5 , $1 \%$, respectively. Group 9 and 10 rats take milk inoculated with B. cereus $8 \log _{10} \mathrm{CFU} / \mathrm{ml}$ and CNPs $0.5,1 \%$, respectively. Each rat from tested groups was daily inoculated with $2 \mathrm{ml}$ volume of treated milk by oral gavage for 15 days. At the end of experiment all rats groups were individually weighed, euthanatized and sacrificed for tissue specimens' collection.

\section{Pathological studies}

At the end of experiment, on $15^{\text {th }}$ day, all rats were sacrificed, examined for postmortem findings. Tissue specimens from intestine and liver were collected, fixed in $10 \%$ neutral buffer formalin, dehydrated, cleared, and embedded in paraffin blocks. Paraffin sections of $4 \mu \mathrm{m}$ thickness were prepared and stained by Hematoxylin \& Eosin (Suvarna et al., 2013), and examined microscopically for detection of histopathological alterations.

\section{Statistical analysis}

The effect of different concentrations of the chitosan and its nanoparticles on $B$. cereus count in pasteurized milk was analyzed using one-way analysis of variance and repeated measures ANOVA and the differences among group means were analyzed using the Tukey's multiple comparisons test. A p-value of $<0.01$ was considered significant. The Graph Pad Prism software (GraphPad, Inc., San Diego, USA) (version 5) was employed for the statistical analysis.

\section{RESULTS}

\section{The prevalence of emetic B. cereus strains in some food samples}

The incidence of $B$. cereusin 150 examined samples were 40, 52 and $62 \%$ with mean count of $3.9 \pm 0.3,4 \pm 0.7$ and $4.7 \pm 0.3 \log _{10} \mathrm{CFU} / \mathrm{ml}$ of raw milk, cooked rice with milk and mehalabia samples, respectively (Table 1). The maximum count of B. cereus in this study was reported in mehalabia samples $\left(\log _{10} 5.7 \mathrm{CFU} / \mathrm{ml}\right)$ (Table 1). The toxic gene profiles indicated that ces, the specific gene for emetic B. cereus strain, was detected (Photo 1,2 and 3).

Table 1 Incidence and count of B. cereus in the examined samples

\begin{tabular}{|c|c|c|c|c|c|}
\hline \multirow{2}{*}{ Samples } & \multicolumn{5}{|c|}{$\begin{array}{c}\text { Positive samples } \\
\left(\log _{10} \mathrm{CFU} / \mathrm{ml}\right)\end{array}$} \\
\hline & \multicolumn{2}{|c|}{$\begin{array}{c}\text { No./50 } \\
\%\end{array}$} & \multirow{2}{*}{$\begin{array}{r}\text { Min. } \\
2.0 \\
\end{array}$} & \multirow{2}{*}{$\begin{array}{r}\text { Max. } \\
5.6\end{array}$} & $\begin{array}{l}\text { Mean } \\
\pm \text { StD }\end{array}$ \\
\hline Raw milk & 20 & 40 & & & $3.9 \pm 0.3$ \\
\hline Cooked rice with milk & 26 & 52 & 2.0 & 5 & $4 \pm 0.7$ \\
\hline Cooked rice with milk & 31 & 62 & 2.0 & 5.7 & $4.7 \pm 0.3$ \\
\hline
\end{tabular}

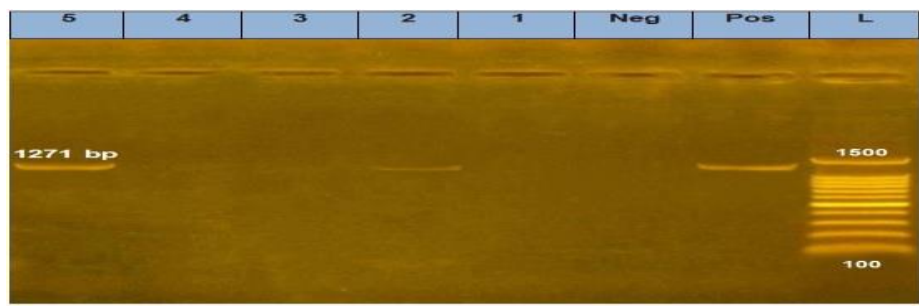



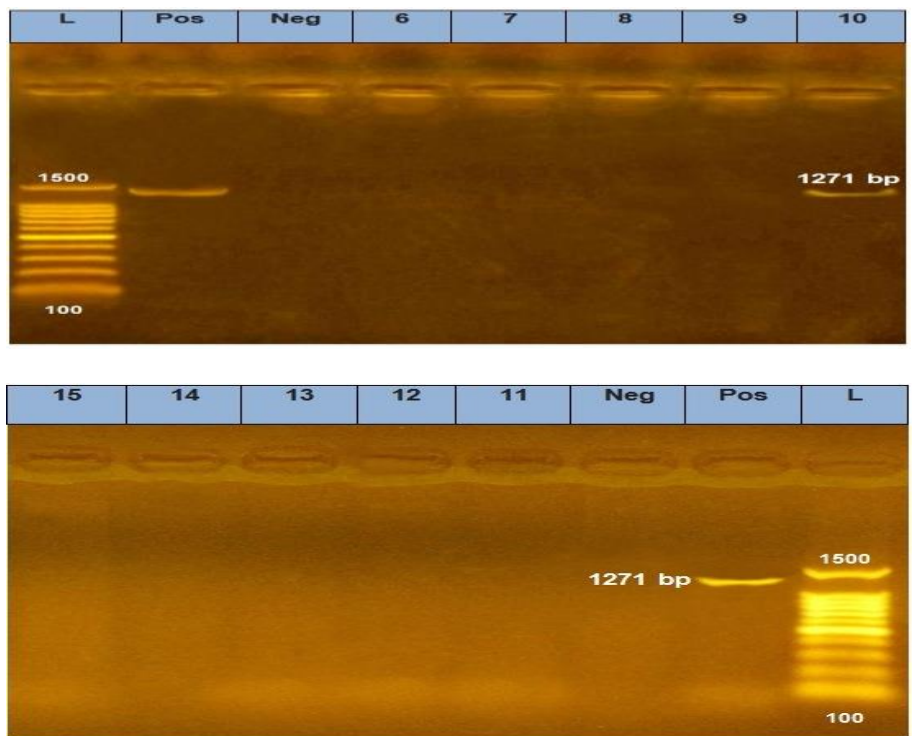

Photo 1, 2, 3 Gel electrophoresis of the PCR amplification products obtained with toxic gene of cereulide (ces). Emetic B. cereus strains (lanes 2, 5 and 10) and non-emetic B. cereus strains (lanes 1, 3, 4, 6-9 and 11-15). L. Molecular marker, Lane pos. Positive control, Lane Neg. Negative control.

The antibacterial efficacy results of chitosan and CNPs to inhibit the growth of $B$. cereus.

Regarding the effect of different concentrations of chitosan and CNPs on $B$. cereus count inoculated in pasteurized milk. Firstly, detect the size and shape of nanoparticles using TEM as shown in photo (4). Also, detection of freshness by clot on boiling test which revealed positive results by the $13^{\text {th }}$ day of the experiment in positive control sample and in pasteurized milk inoculated by $0.5 \%$ chitosan samples so, these samples were not tested (Table 2). In this study, the mean $\mathrm{pH}$ value of pasteurized milk control sample ranged from $6.8 \pm 0.04$ to $3.4 \pm 0.2$ by the end of the experiment. While by adding chitosan to pasteurized milk, it ranged from $6.8 \pm 0.05$ to $4.2 \pm 0.09$ and $5.8 \pm 0.04$ in concentrations 0.5 and $1 \%$, respectively. Nearly similar values obtained in pasteurized milk sample with CNPs. It reached $5.7 \pm 0.07$ and $5.9 \pm 0.08$ at day $15^{\text {th }}$ of the experiment for concentration 0.5 and $1 \%$ of CNPs, respectively (Table 2 ). It was found that $B$. cereus mean count decreased from $8 \log _{10} \mathrm{CFU} / \mathrm{ml}$ at zero time to $3.8 \log _{10}$ $\mathrm{CFU} / \mathrm{ml}$ in positive control sample after $11^{\text {th }}$ days of storage at $4 \pm 1{ }^{\circ} \mathrm{C}$ (Table 3 ) On the other hand, both concentrations of chitosan 0.5 and $1 \%$ had displayed antibacterial activity against $B$. cereus $\left(1.10\right.$ and $1.2 \log _{10} \mathrm{CFU} / \mathrm{ml}$ at the $7^{\text {th }}$ day of the experiment). CNPs still had good bactericidal activity at concentration $0.5 \%$ after 7 days from cooling storage comparing with positive control group at which the bacterial growth mean count reached $6.5 \log _{10} \mathrm{CFU} / \mathrm{ml}$ as shown in Table (3) The most prominent potent bactericidal effect was observed inCNPs $1 \%$ in which $B$. cereus count reached to undetectable level at the $5^{\text {th }}$ day of refrigerated storage.

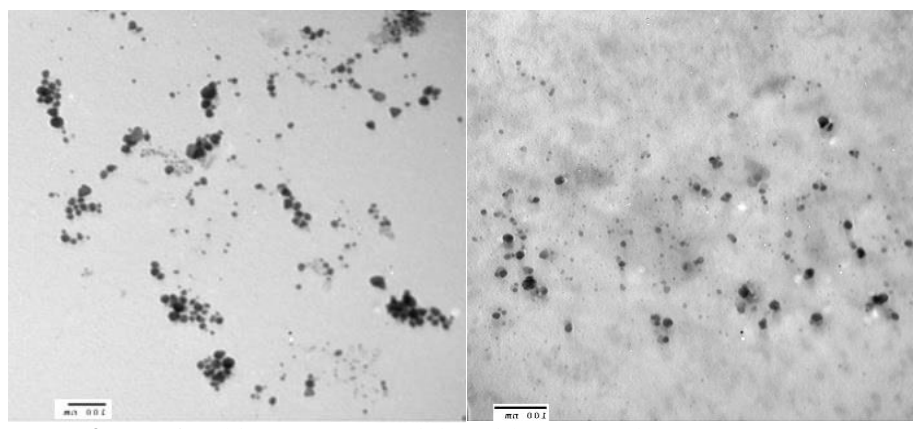

Photo 4 TEM for chitosan nano-particles with average size $27.6 \mathrm{~nm}$.

Table 2 Mean $\mathrm{pH}$ and detection of freshness of pasteurized milk treated with chitosan and CNPs

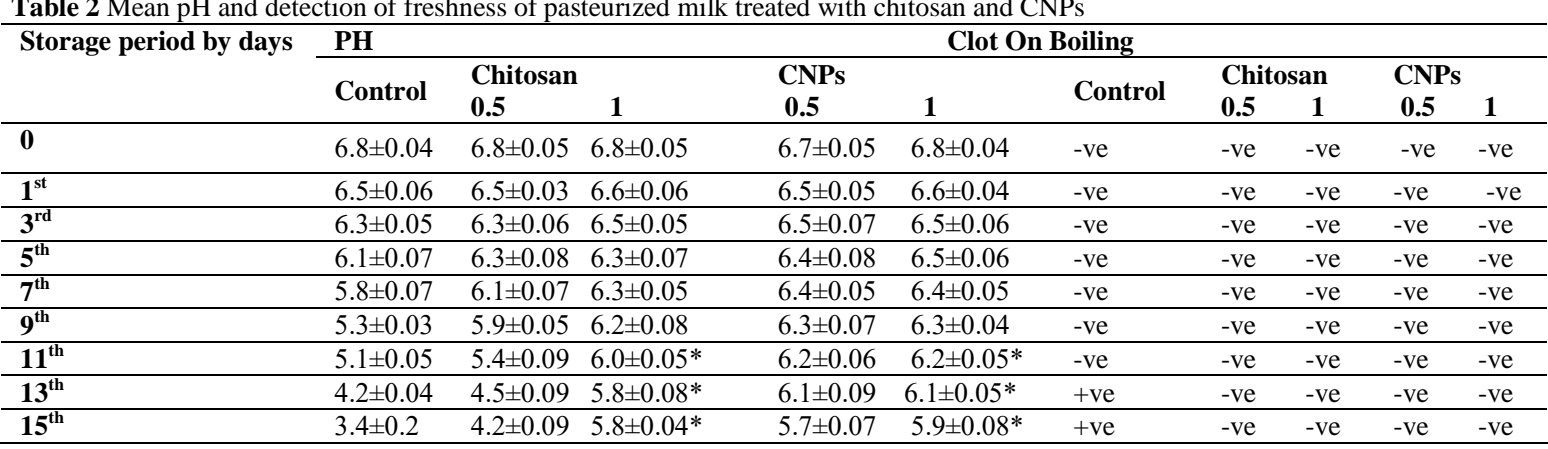

Mean \pm SE of five replications

*Significant difference $(\mathrm{P}$ value $<0.01)$

Table 3 Effect of incorporation of different concentrations of chitosan and CNPs on B. cereus count $(\log 10 \mathrm{CFU} / \mathrm{ml})$ inoculated in pasteurized milk stored at $4 \pm 1{ }^{\circ} \mathrm{C}$

\begin{tabular}{|c|c|c|c|c|c|c|}
\hline \multirow[t]{2}{*}{ Storage period by days } & \multicolumn{2}{|c|}{ Control } & \multicolumn{2}{|c|}{ Chitosan } & \multicolumn{2}{|c|}{ CNPs } \\
\hline & -ve & $+\mathrm{Ve}$ & $0.5 \%$ & $1 \%$ & $0.5 \%$ & $1 \%$ \\
\hline 0 & -ve & 8 & 8 & 8 & 8 & 8 \\
\hline $1^{\mathrm{st}}$ & -ve & 8.3 & 7.8 & 6.11 & 7.9 & 6.7 \\
\hline $3^{\text {rd }}$ & -ve & 8.6 & 6.8 & 3 & 5.3 & $3.7^{*}$ \\
\hline $5^{\text {th }}$ & -ve & 7.9 & 3 & 2.8 & $2.4 *$ & $\mathrm{ND}$ \\
\hline $7^{\text {th }}$ & -ve & 6.5 & $1.10^{*}$ & $1.2 *$ & ND & ND \\
\hline $9^{\text {th }}$ & -ve & 5.7 & ND & ND & ND & ND \\
\hline $11^{\text {th }}$ & -ve & 3.8 & ND & ND & ND & ND \\
\hline $13^{\text {th }}$ & -ve & NT & NT & $\mathrm{ND}$ & ND & $\mathrm{ND}$ \\
\hline $15^{\text {th }}$ & -ve & NT & NT & ND & ND & ND \\
\hline
\end{tabular}

ND. Not Detected (below than one $\log _{10} \mathrm{CFU} / \mathrm{ml}$ )

NT. Not Tested (due to deterioration of samples which detected by $\mathrm{pH}$ and clot on boiling test as shown in table 2)

Mean of five replications

*Significance difference $(\mathrm{P}$ value $<0.01)$. 


\section{B- Flavor}
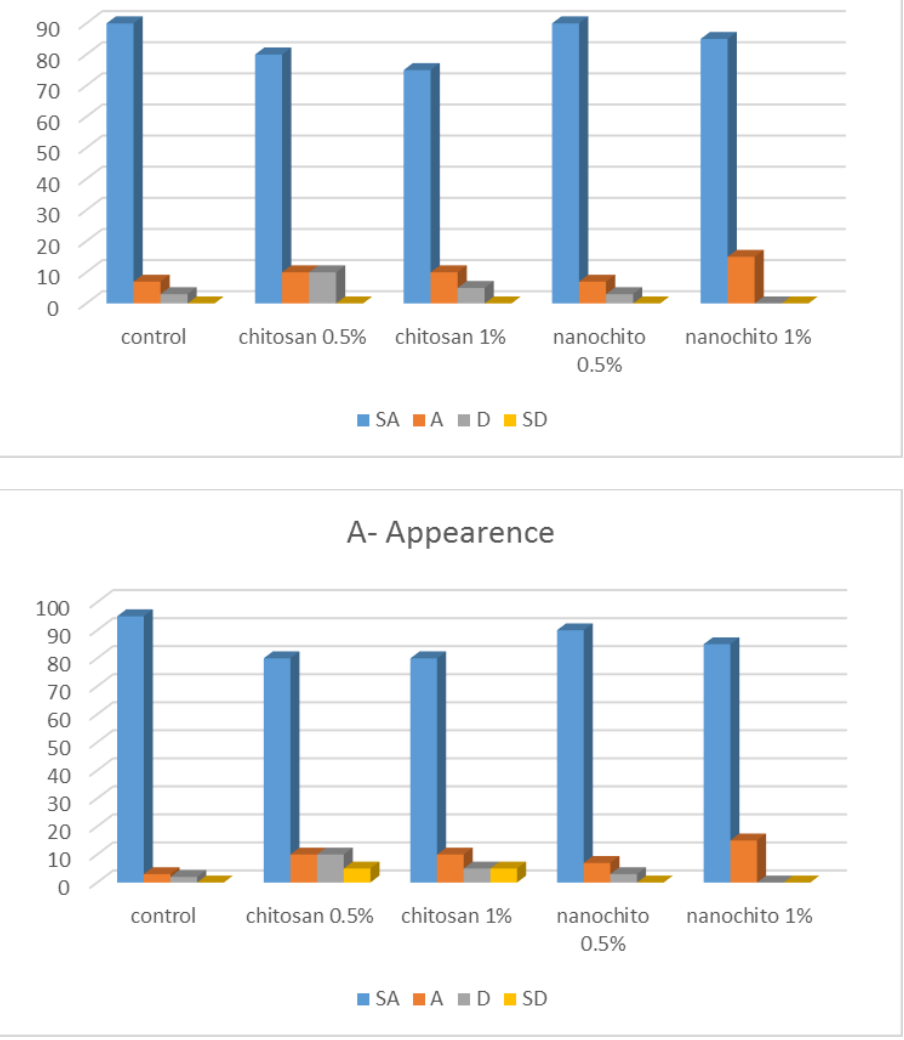

Figure 1 Level of agreement of consumer acceptability to appearance (A), and flavor (B) of Pasteurized milk inoculated with different concentrations of chitosan and CNPs.
Body weight. No significant changes were observed in the values of body weight in different experimental groups along the period of the experiment.

\section{Pathological findings}

Postmortem examination: No characteristic gross of pathological lesions in rats of different groups except group (2) which administrated milk with B. cereus (8 $\left.\log _{10} \mathrm{CFU} / \mathrm{ml}\right)$, most rats showed mild congested and hyperemic intestine and enlarged pale liver.

\section{Light microscopic examination.}

The intestinein Group 1 (control negative) and Groups 3, 4 and 5 showed normal structure of intestinal villi with intact lamina epithelialis (Fig 2 A, B and C) While, The liver of same group's demonstrated normal hepatic parenchyma (Fig 3 A, B). In Group (6), rats take milk with $1 \%$ CNPs revealed mild edema appeared at the tip of some villi of the intestine (Fig 2D and E) and mild proliferation of kupffer cells in sinusoids of liver (Fig $3 \mathrm{C}$ ). Control positive milk with B. cereus only (Group 2) showed swollen villi, goblet cells hyperplasia, some villi appeared blunted associated with congestion of lamina propria and edema in submucosa (Fig $2 \mathrm{~F}, \mathrm{G} \& \mathrm{H}$ ). While, the liver of the same group showed characteristic vacuolar hepatocytes degeneration, perivascular mononuclear cells infiltration and kupffer cells proliferation in perivascular and hepatocyte plates (Fig 3 D \& E). Group (7) which rats take milk with B. cereus and $0.5 \%$ chitosan, the intestine showed mild hyperplasia of goblet cells and slight aggregation of mononuclear inflammatory cells in villus core (Fig 2 I \& J) and the liver showed mild vacuolar degeneration of hepatocytes (Fig 3 F). In Group (8), the intestine appeared almost normal mucosa except for slight increase in goblet cells population (Fig $2 \mathrm{~K} \& \mathrm{~L}$ ) and liver showed almost normal hepatocytes (Fig $3 \mathrm{G}$ ). On the other hand, Group (9) which rats take milk with B. cereus and $0.5 \%$ CNPs, the intestine showed increase population of goblet cells and some villi showed slight edematous tips with mild vacuolar degenerative changes in overlying epithelium (Fig $2 \mathrm{M}$ and $\mathrm{N}$ ). In addition, the liver showed mild necrobiotic changes of hepatocytes (Fig $3 \mathrm{H}$ ). In group (10) which rats take milk with $B$. cereus and $1 \%$ CNPs, intestinal villi showed nearly normal mucosa except for appearance of edema at the tips of some villi (Fig $2 \mathrm{O} \& \mathrm{P}$ ), liver showed mild sinusoidal dilatation and some engorged with RBCs accompanied by kupffer cells activation (Fig 3 I ).
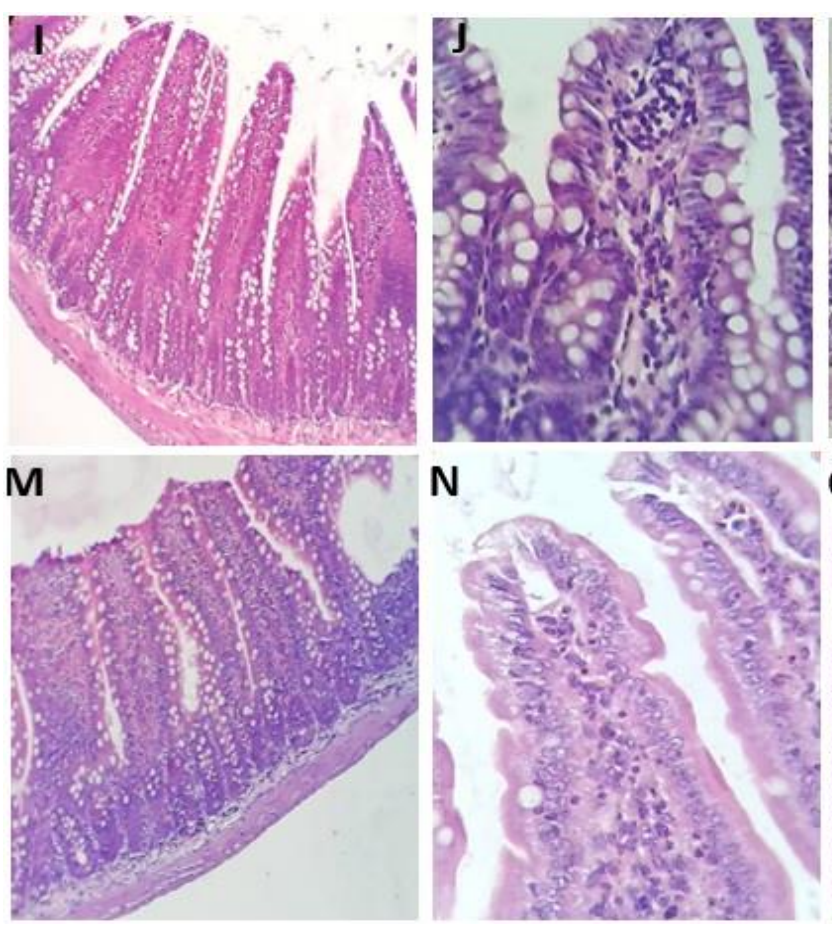
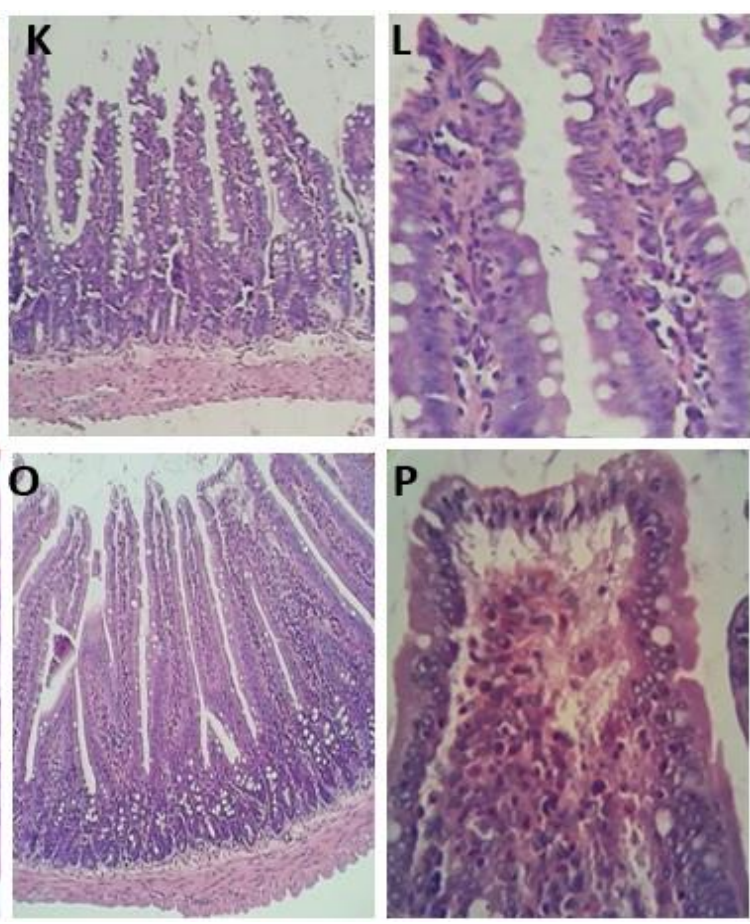

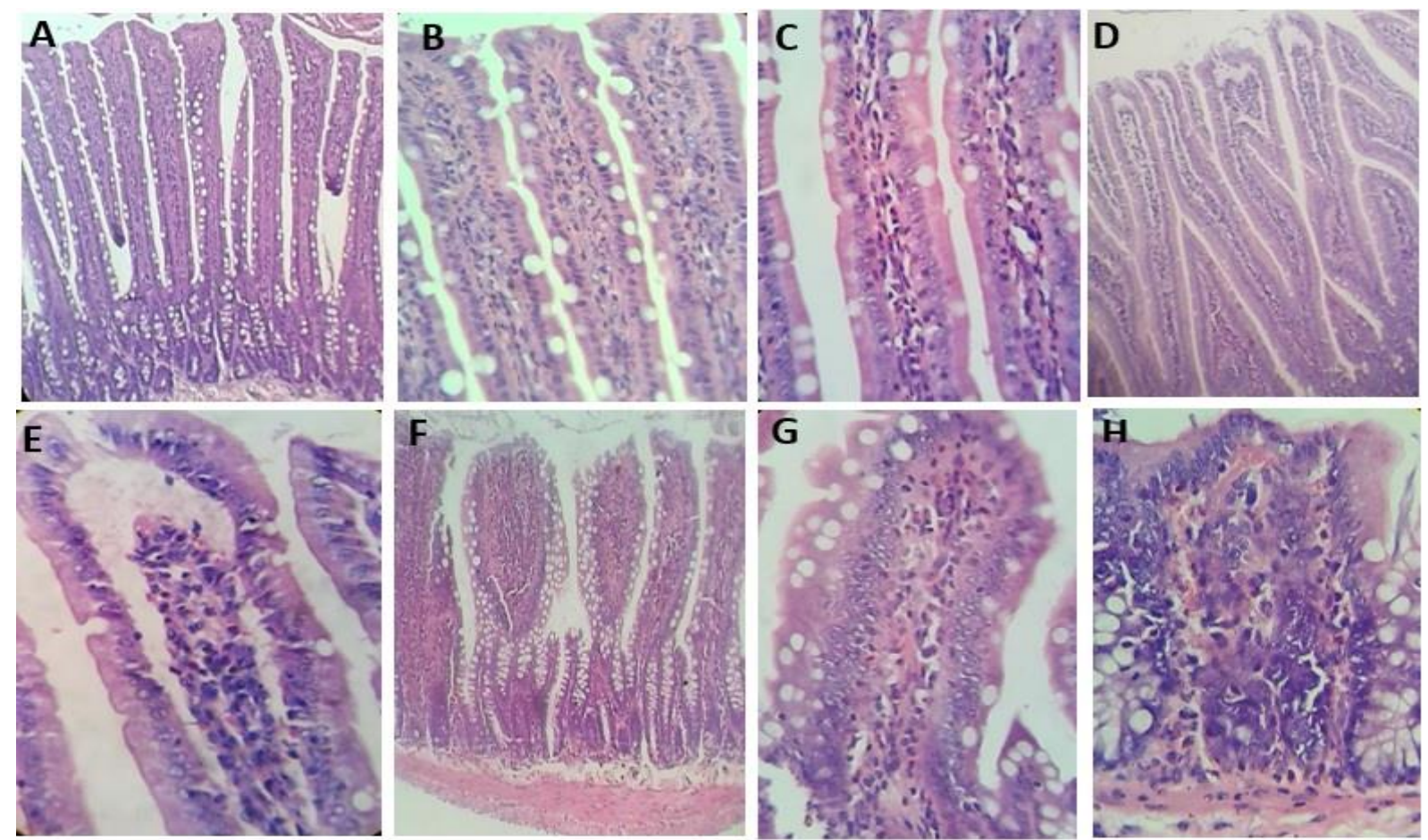

Figure 2 photomicrograph of rat intestine in different groups, panels show (A\&B) normal mucosa of intestinal villi and the higher magnification (x400) from group (1,3 and 4). (C) Almost normal intestinal villi from group (5). (D\&E) mild edema appeared at the tips of villi and the higher magnification (x400) from group (6). (F, G\&H) swollen villi, goblet cells hyperplasia and edema in submucosa, and the high power from group (2). (I\&J) mild goblet cells hyperplasia and the high power view slight aggregate of mononuclear cells in villus core from group (7). (K\& L) almost normal mucosa except for slight increase in goblet cells and the higher magnification from group (8). (M\&N) increase population of goblet cells and the high power view mild edema at the tip of villi from group (9). (O\&P) nearly normal mucosa except for appearance of edema at the tips of villi and the higher power from group (10). (H\&E stain low power x100, high power x400)
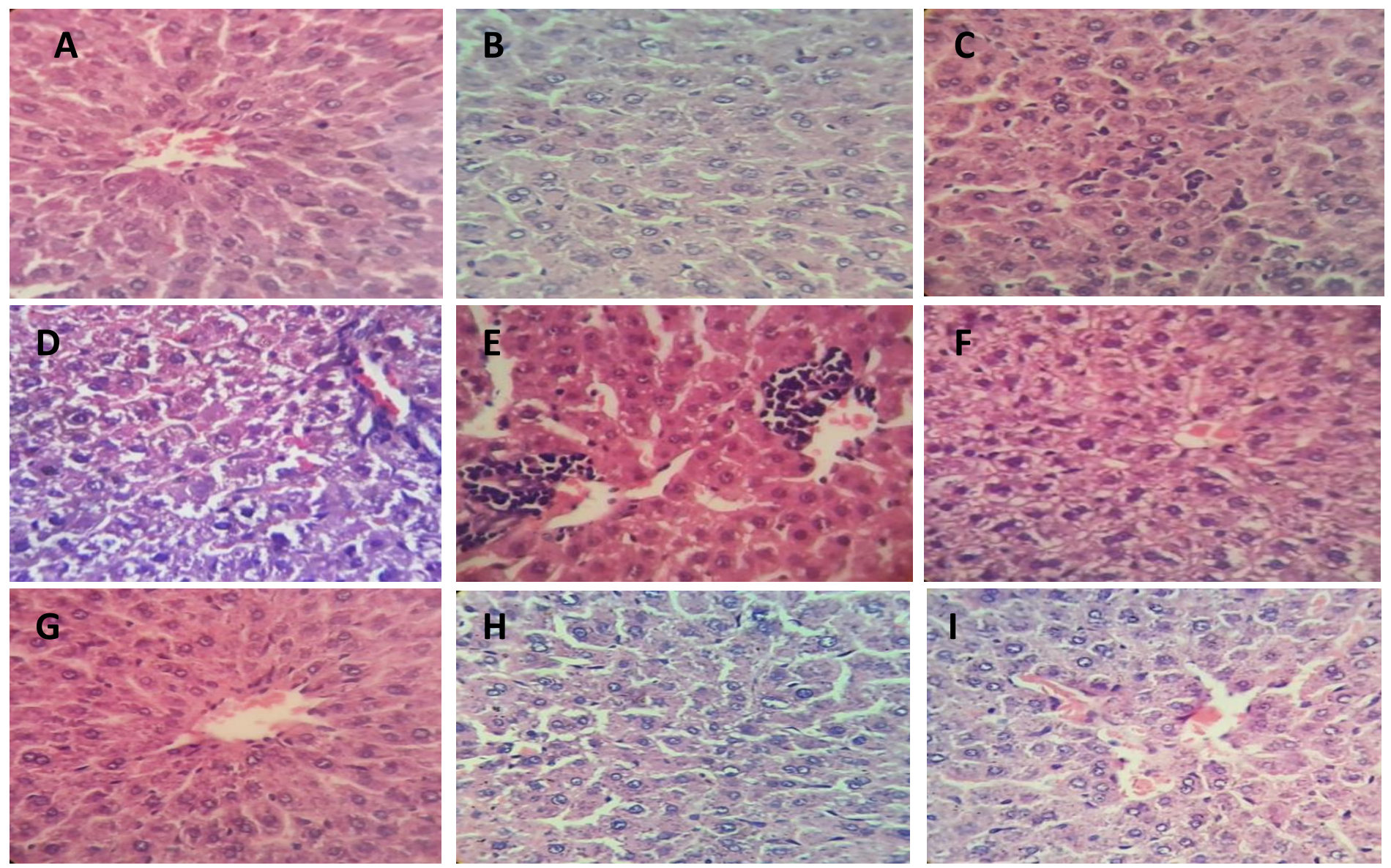

Figure 3 photomicrograph of rat liver in different groups, panels show (A) normal hepatic parenchyma from group (1, 3, 4). (B) Almost normal hepatic tissue from group (5). (C) Mild kupffer cells activation from group (6). (D\&E) hepatocellular vacuolar degeneration, clumps of lymphocytes and kupffer cells in hepatic parenchyma from group (2). (F) Mild hepatocellular vacuolar degeneration from group (7). (G) Almost normal hepatocytes from group (8). (H) Mild necrobiotc changes in hepatocytes from group (9). (I) Mild dilatation of sinusoids and activation of kupffer cells from group (10). (H\&E stain x400) 


\section{DISCUSSION}

The combined abilities of $B$. cereus spores and toxins, to survive in pasteurization and of certain strains to multiply at low temperatures make this organism a unique milk-borne pathogen. Since $B$. cereus grows best in a starch-rich environment (Samapundo et al., 2011), cooked rice with milk and Mehalabia are popular dessert prepared and sold all day by dairy shops or local restaurants in Egypt and many middle east countries. They produced by adding whole rice grains or rice flour or cornstarch to milk, cooked and stored at refrigeration temperature. In the present study, high incidence of B. cereus (52 and 62\%) was reported in cooked rice with milk and mehalabia compared to raw milk samples. These investigated dairy products are all known to be subjected to different types of heat treatment during processing according to each product. Heat treatment is not completely efficient to eliminate spore-forming bacteria in foods, among Bacillus spp. This high incidence may be attributed also to the improper temperature control during storage of such products. Similar incidences were reported by Organji et al. (2015) and Mohamed $\boldsymbol{e t}$ al. (2016). It was reported that $B$. cereus increase rapidly in boiled rice to $7-8 \log _{10} \mathrm{CFU} / \mathrm{g}$ and produced emetic toxin at both $30-35^{\circ} \mathrm{C}$ (Agata et al., 2002). Several studies detected $B$. cereus emetic strains in various foods (Mudagza and Buys, 2017, Yang et al. 2017; Frentzel et al., 2018). Only a minority of B. cereus isolates may produce cereulide but the detection at least of one toxin gene could be a target marker for screening toxigenic B. cereus group strains in food (Gdoura-Ben et al. 2018). The present article demonstrated that strains of $B$. cereuswhich isolated from milk and dairy desserts may contain genes encoding the toxic gene (ces), so the risk of food poisoning should not be neglected. For that reason, our present study was focused on the application of chitosan and CNPs in pasteurized milk contaminated with $B$. cereus as an example of spoilage and pathogenic microorganism. Significant decrease in B. cereus count was noticed in treated pasteurized milk with different concentrations of chitosan and the organism could not be detected by the $9^{\text {th }}$ day of the experiment. While, by adding CNPs $(0.5$ and $1 \%$ ), the count could not be detected at $7^{\text {th }}$ and $5^{\text {th }}$ days of storage, respectively. On the other hand no significance differences $(\mathrm{p}>0.05)$ were observed between concentrations of chitosan and CNPs.

The effectiveness of chitosan on gram-positive or gram-negative bacteria is however, somewhat controversial. Several studies (Dutta et al., 2009; Zaghloul \& Ibrahim 2019) detected the bactericidal effectiveness of chitosan, others stated that chitosan exhibited a bacteriostatic effect on all bacteria tested including B. cereus (Benhabiles et al., 2012). Raafat et al. (2008) declare one of the suggested hypothesis for this effect, who stated that, this difference in sensitivity is largely ascribed to the different structure of Gram positive and Gram-negative bacterial cell envelopes. As a possible mechanism of action for chitosan, antimicrobial activity is due to binding to teichoic acids present in the cell wall of Gram-positive bacteria, coupled with membrane lipids extraction, which trigger a series of event that resulted in bacterial cell death. Tamara et al. (2018) showed that B. cereus was generally more resistant to the CNPs and suggested that $B$. cereus had more hydrophilic and negatively charged cellula structure. Another study (Hassan et al., 2016) investigated that the antibacteria activity of CNPs on bacillus spp. was recorded in percentage $100 \%$ inhibition a different concentrations. Furthermore, CNPs can be used as bioactive ingredients carriers and in wide approach arrays, due to their favorable biological properties such as non-toxicity, biocompatibility, biodegradability and antibacterial ability (Zhao et al., 2011). Increasing the degree of de-acetylation has a major effect on the antimicrobial activity of chitosan and in dependency CNPs, that due to increase the free amino groups in the produced chitosan, which leads to higher antimicrobial activity, as the $-\mathrm{NH} 2,-\mathrm{OH}$ groups are the main reactive site in chitosan. As, it is determinant in the charge development and solubility of chitosan (Zaghloul and Ibrahim, 2019).

CNPs have been very effective in increasing the shelf life of different meats and their products (Quesada et al., 2016). In the present study, the shelf life of pasteurized milk with chitosan and CNPs was extended compared to control samples. Clot on boiling test was used to detect freshness of pasteurized milk Positive control and pasteurized milk with $0.5 \%$ chitosan samples soured by the $13^{\text {th }}$ day of the experiment so, these samples were not tested. On the other hand, the shelf life of pasteurized milk extended more than 15 days by adding $1 \%$ chitosan, 0.5, and 1\% CNPsas shown in table (2). Generally, treated milk either by chitosan or CNPs were considered the most preferable and strongly accepted as nearly no difference from control as shown in Figure (1). That may be the chitosan in nature white color and have no special taste or flavor so, haven't effect on flavor or appearance.

Although chitosan produce potent bactericidal effect against most bacterial forms, neverthless it is important to examine the constituents of the food matrix (Awad and El Sohaimy, 2020). The change in $\mathrm{pH}$ value by adding chitosan and CNPs should be taken into consideration before apply chitosan as a natura preservative. Chitosan was reported to be positively charged and have high antimicrobial activity, mainly at $\mathrm{pH}$ values below its $\mathrm{pKa}$ of 6.5 (Chang $\boldsymbol{e t}$ al. 2015). The molecular weight and viscosity development of chitosan in aqueous solution also play a significant role in the biochemical and pharmacological application of chitosan. Other major parameters are crystallinity, ash content, moisture content, heavy metal content and so on (Rinaudo, 2006). On the other hand, CNPs are natural materials with excellent physicochemical, antimicrobial and biological properties, which make them a superior environmentally friendly material and they possess bioactivity that does not harm humans (Malmiri et al. 2012; Elsherif and Ali, 2019).

Regarding to histopathological findings, The hyperplasia of villous goblet cells associated with congested lamina propria in-group (2) were considered to be a result of $B$. cereus enterotoxins which responsible for diarrheal symptoms (Granum and Lund, 1997). Furthermore, the vacuolar degeneration of hepatocytes, perivascular and around hepatocyte plates aggregation of lymphocyte and kupffer cells observed in liver of B. cereus exposed rat (group 2) could be due to the effect of $B$. cereus, cereulide, toxin on hepatocytes mitochondria. Yokoyama et al. (1999) have also previously reported vacuoles in the cytoplasm of hepatocytes in precentral area of hepatic lobule associated with proliferation of kupffer cells in sinusoids of mice treated with cereulide Moreover, attributed the hepatocytes vacuolar degeneration to disruption caused by cereulide toxin on mitochondrial membrane potential and de-energize mitochondria leading to impair mitochondrial fatty acid metabolism and accumulation of vacuoles in the cytoplasm (Mahler et al., 1997; Inai et al., 1997)

With regarding to the effect of chitosan and CNPs on $B$. cereus in groups $(7,8,9$ and 10) at both concentrations $0.5 \%$ and $1 \%$ we found that both of CNPs and large molecule chitosan had antibacterial effect on B. cereus and markedly reduced its enterotoxins degenerative effects on intestine and liver. However, it was observed that the large molecule chitosan especially higher concentration $1 \%$ had much better antibacterial effect without cytotoxic effects on rat's intestinal villi in-compared to the same concentration $1 \%$ of CNPs, which exerted degenerative action on intestinal epithelium similar to group (6). In spite of antibacterial effect of $1 \%$ CNPs on $B$. cereus and its toxin, but it has mild side effect on biological tissue. While, this cytotoxic effect was less prominent with lesser concentration $(0.5 \%)$ of CNPs. Our findings are inconsistent with those previously reported by Tokura $\boldsymbol{e t}$ al., (1996) who mentioned that large chitosan molecules revealed greater antibacterial activates than smaller chitosan molecules. Additionally, the report of Islam et al., (2011) indicated that a concentration of $1.2 \mathrm{mg} / \mathrm{ml}$ of chitosan molecules had a good inhibitory activity against Staph aureus. On the other hand, some studies demonstrated that chitosan polymerization exhibited low activity against $E$. coli (Zheng and Zhu, 2003). In a study of Ardila et al. (2017a) indicated that the antimicrobial properties of chitosan needs at least partial solubilisation additionally requires a direct contact between chitosan and the microbial cell surface for antibacterial activity of chitosan. Suggested that one part of antimicrobial effect of chitosan is exerted by the direct contact protonated chitosan powder with negatively charged bacterial cell wall, and the other, may exert by deposition of solubilized chitosan on bacterial surface affecting the cell permeability resulted in leakage of intracellular constituents (Kong et al., 2008; Arkoun et al., 2017). However, in another study of Ardila et al., (2017b) and Elsherif et al., (2020) investigated that the antimicrobial activity of CNPs is independent of the size and form of bacterial cells.

the edematous tips of intestinal villi, which observed in rats administrated milk with $1 \%$ CNPs of group (6) and confirmed by its appearance again in group (10) which take milk inoculated with $B$. Cereus $8 \log _{10} \mathrm{CFU} / \mathrm{ml}$ and CNPs $1 \%$ in spite of disappearance of cereulide toxic effect on liver hepatocytes of group (10). This probably returned to the cytotoxic activity of higher concentration of $1 \%$ chitosan nanoparticles on intestinal villous epithelium. Previous studies have evaluated the cytotoxicity of chitosan nanoparticles (Huang et al., 2004; Qi et al., 2005; Kamjumphol et al., 2017; Hassanen et al., 2019), which may be more critical than natural large chitosan molecules, because the nanoparticles could penetrate the cells through pervasion, modified the mechanism of cellular uptake and alter the function of DNA and mRNA. Qi et al. (2005) reported a similar explanation, as they found that cytotoxic activity of CNPs against normal human hepatic cells In addition, these results in agreement with Loh et al. (2010) who reported the cytotoxicity of $1 \%$ CNPs on human liver cells through uptake of it into the cell nucleus was observed by confocal microscopic analysis after $4 \mathrm{~h}$ exposure with $1 \% \mathrm{w} / \mathrm{v}$ of chitosan nanoparticles. Electron micrographs further suggest necrotic or autophagic cell death, possibly caused by cell membrane damage and resultan enzyme leakage and normal cells at $0.5 \%$ concentration of CNPs. While, the liver of the same group (6) showed mild kupffer cells proliferation in sinusoids, this could be attributed to the immune stimulatory effect of CNPs (Yeh $\boldsymbol{e t}$ al. 2017). Where, it has been found to have a variable of biological properties including antimicrobial effects, activation of macrophages and accelerate wound healing through enhanced inflammatory cells infiltration in the area of injury (Rinaudo, 2006; Prabaharan, 2008)

\section{CONCLUSION}

This study demonstrated that the toxin gene ces is present in some strains of $B$ cereus isolated from some of raw milk and dairy desserts samples. Therefore, effective prevention and control measures of emetic B. cereus in food is demanded. Both chitosan and CNPs showed antibacterial activity in treated pasteurized milk against B. cereus. The shelf life of pasteurized milk with chitosan and CNPs solution was extended in compared to control samples. 
Furthermore, CNPs will be used increasingly in the fields of food storage, preservation and microbial inhibition with excellent physicochemical, antimicrobial and biological properties, which make them a superior environmentally friendly material and they possess bioactivity that does not harm humans. The results of experimental study revealed that chitosan $1 \%$ and CNPs $0.5 \%$ can be applied safely against B. cereus in dairy products without harmfu effects on biological tissues.

Acknowledgement: This work was supported byReference Lab. for Food Safety, Animal Health Research Institute (AHRI), Agriculture Research Center (ARC), Egypt.

\section{REFERENCES}

Agata, N., Ohta, M. \&Yokoyama, K. (2002). Production of Bacillus cereus emetic toxin (cereulide) in various foods. Int. J. Food Microbiol., 73: 23 27.DOI: 10.1016/s0168-1605(01)00692-4

Alvarenga, V., Brancini, G., Silva, E., Da Pia, A., Campagnollo, F., Braga, G., Hubinger, M.\& Sant'Ana, A. (2018). Survival variability of 12 strains of Bacillus cereus yielded to spray drying of whole milk. Int. J. Food Microbiol. 286:80 89.doi.10.1016/j.ijfoodmicro.2018.07.020. Epub 2018 Jul 17.

APHA "American Public Health Association" (1998). Standard Methods for examination of Dairy Products, $17^{\text {th }}$ edn., Washington D.C. USA, 144 and $147-$ 148 pp.

Ardila, N., Daigle, F., Heuzey, M.C.\& Ajji, A. (2017a). Effect of chitosan physical form on its antibacterial activity against pathogenic bacteria. J. Food Sci. 82(3):679-686.https.//doi.org/10.1111/1750-3841.13635

Ardila, N., Daigle, F., Heuzey, M-C. \& Ajji, A. (2017b). Antibacterial Activity of Neat Chitosan Powder and Flakes. Molecules, 22(1) 100,doi.10.3390/molecules22010100

Arkoun, M., Daigle, F., Heuzey, M.-C.\& Ajji, A. (2017). Antibacteria electrospun chitosan-based nanofibers: A bacterial membrane perforator. Food Sci. Nutr. 2017. doi: 10.1002/fsn3.468. eCollection 2017 Jul

Awad, D. A. \& El Sohaimy, S. A. (2020). Evaluation the Efficacy of Lysozyme Hydrolysates-Loaded Chitosan Against Food Borne Pathogens in Raw Milk During Cooling Storage. AJVS. 64 (1): 86-96. DOI.10.5455/ajvs.79825

Benhabiles, M. S., Salah, R., Lounici, H., Drouiche, N., Goosen, M. F. A.\& Mameri, N. (2012). Antibacterial activity of chitin, chitosan and its oligomers prepared from shrimp shell waste. Food Hydrocolloids, 29, 4856.https://doi.org/10.1016/j.foodhyd.2012.02.013

Calvo, P., Remunan-Lopez, R., Vila-Jato, C.J.L.\& Alonso, M.J. (1997). Chitosan and chitosan/ethylene oxide-propylene oxide block copolymer nanoparticles as novel carriers for proteins and vaccines. Pharm. Res. 14, 14311436.https://doi.org/10.1023/A:1012128907225

Ceuppens, S., Rajkovic, A., Hamelink, S., Van, T., Boon, N.\& Uyttendaele, M. (2012). Enterotoxin production by Bacillus cereus under gastrointestinal conditions and their immunological detection by commercially available kits. Foodborne Pathol Dis. 9:1130-6.http://doi.org/10.1089/fpd.2012.1230 Chang, S.H., Lin, H.T.V., Wu, G.J.\& Tsai, G.J. (2015). pH Effects on solubility, zeta potential, and correlation between antibacterial activity and molecula weight of chitosan. Carbohydr. Polym. 2015, 134, 74-81.doi: 10.1016/j.carbpol.2015.07.072. Epub 2015 Jul 26.

Chica, J S, Correa, M M, Aceves-Diez, A E, Rasschaert, G, Heyndrickx, M \& Castan eda-Sandoval, L M. (2019). Genomic and Toxigenic Heterogeneity of Bacillus cereus sensu lato Isolated from Ready-to-Eat Foods and Powdered Milk in Day Care Centers in Colombia. Foodborne Patho. Dis. Volume XX, Number XX, 2019. DOI: 10.1089/fpd.2019.2709

Dutta J. \& Dutta P. K. (2011). Antimicrobial activity of chitin, chitosan and their oligosaccharides. In: Kim SK, editor. Chitin, Chitosan, Oligosaccharides and Their Derivatives: Biological Activities and Aplications. New York: CRC Press, p. 195-209.

Dutta, P.K., Tripath, S., Mehrotra, G.K. \& Dutta, J. (2009). Perspectives for chitosan based antimicrobial films in food applications. Food Chem., 114: 11731182.DOI: 10.1016/j.foodchem.2008.11.047

Ehling-Schulz, M., Guinebretiere, M., Monthán, A., Berge, O., Fricker, M. \& Svensson, B. (2006). Toxin gene prodling of enterotoxic and emetic Bacillus cereus. FEMS Microbiol Lett 260: 232-240.doi: 10.1111/j.15746968.2006.00320.x.

Elsherif, M. W., El Hendy A. H. M., Elnisr N. A. \& Zakaria M. I. (2020) Ameliorative effect of zeolite packaging on shelf life of milk. J. Pack. Tech. Res.doi.org/10.1007/s41783-020-00093-x.

Elsherif, W. M. \& ALID. N. (2019). Antibacterial effect of silver nanoparticles on antibiotic resistant $E$. coli $\mathrm{o} 157: \mathrm{h} 7$ isolated from some dairy products. Bul. J. of Vet. Med., 2019. DOI: 10.15547/bjvm.2019-0027

Fasken, J. E. \& McClure, A. D. (1940). The Phosphatase Test in Pasteurization of Milk. Can J Comp Med Vet Sci. 1940 May, 4(5): 128-133, 136137.https://europepmc.org/article/med/17647644

Fernandes, J. C., Eaton, P., Gomes, A. M., Pintado, M. E.\& Malcata, F. X (2009). Study of the antibacterial effects of chitosans on Bacillus cereus (and its spores) by atomic force microscopy imaging and nanoindentation Ultramicroscopy 109: 854-860. https://doi.org/10.1016/j.ultramic.2009.03.015

Frentzel, H., Kraushaar, B., Krause, G., Bodi, D., Wichmann- Schauer, H. Appel, B.\& Mader, A. (2018). Phylogenetic and toxinogenic characteristics of Bacillus cereus group members isolated from spices and herbs. Food Control. 2018,83:90-98.https://doi.org/10.1016/j.foodcont.2016.12.022

Gdoura-Ben, A. M., Siala, M., Zayani, M., Grosset, N., Smaoui, S., MessadiAkrout, F., Baron, F., Jan, S., Gautier, M.\& Gdoura, R. (2018). Isolation, identification, prevalence, and genetic diversity of Bacillus cereus group bacteria from different foodstuffs in Tunisia. Front Microbiol 2018, 9:447.doi: 10.3389/fmicb.2018.00447. eCollection 2018.

Granum, P.E. \& Lund, T. (1997). Bacillus cereus and its food poisoning toxins. FEMS Microbiol. Lett. 157: 223-228.

Hassan, M. I., Taher, F. A., Mohamed, A. F. \& Kamel, M. R. (2016). Chitosan nanoparticles prepared from LUCILIA CUPRINA MAGGOTS as antibacterial agent. J. Egypt. Soc. Parasitol. (JESP), 46(3): 519 526.DOI: $10.12816 /$ jesp.2016.88251

Hassanen, E. I., Khalaf, A. A., Tohamy, A. F., Mohammed, E. R. \& Farroh, K. Y. (2019). Toxicopathological and immunological studies on different concentrations of chitosan-coated silver nanoparticles in rats. International $\mathrm{J}$. Nanomedicine 2019:14 4723-4739. https://doi.org/10.2147/IJN.S207644

Huang, M., Khor, E.\& Lim, L.-Y. 2004. Uptake and cytotoxicity of chitosan molecules and nanoparticles: Effects of molecular weight and degree of deacetylation. Pharm. Res. 2004, 21, 344-353. https://doi.org/10.1023/B:PHAM.0000016249.52831.a5

Inai, Y., Yabuki, M., Kanno, T., Akiyama, J., Yasuda, T. \& Utsumi, K. (1997) Valinomycin induces apoptosis of ascites hepatoma cells (AH-130) in relation to mitochondrial membrane potential. Cell Struct. Func. 22, 555 563. https://doi.org/10.1247/csf.22.555

Islam M., Masum S. M., Mahbub K. R.\& Haque M. Z. (2011). Antibacterial Activity of crab-chitosan against Staphylococcus aureus and Escherichia coli. J Adv. Sci. Res. 2011, 2(4): 63-66.http://www.sciensage.info/jasr

ISO 7932:2004. Microbiology of Food chain - Horizontal Method for the Enumeration of Presumptive Bacillus cereus - Colony-Count Technique at 30 degrees $\quad \mathrm{C}, \quad$ ISO: Geneva, 2004.https://www.iso.org/standard/38219.html

Kamjumphol W., Chareonsudjai P. \& Chareonsudjai, S. (2017). Antibacterial activity of chitosan against Burkholderia pseudomallei. WWW. Microbiology Open. 2018, 7:e00534. https://doi.org/10.1002/mbo3.534

Kim, H. U. \& Goepfert, J. M. (1971). Occurrence of Bacillus cereus in selected dry food products. J. Milk Food Technol. 34:12-15

Kim, J-B., Kim, J.-M., Cho, S.-H., Oh, H.-S., Choi, N. G., \& Oh, D.-H. (2011) Toxin Genes Profiles and Toxin Production Ability of Bacillus cereus Isolated from Clinical and Food Samples. J. Food Sci.76 (1) 25-29.doi: 10.1111/j.17503841.2010.01958.x.

Kong, M., Chen, X. G., Liu, C. S., Liu, C. G., Meng, X. H.\& Yu, L. J. (2008) Antibacterial mechanism of chitosan microspheres in a solid dispersing system against E. coli. Colloids Surf. B, 65, 197-202.doi: 10.1016/j.colsurfb.2008.04.003

Kumari, S. \& Sarkar, PK. (2014). Prevalence and characterization of Bacillus cereus group from various marketed dairy products in India. Dairy Sci Technol. 94:483-497.https://doi.org/10.1007/s13594-014-0174-5

Loh, J. W.,Yeoh, G.,Saunders, M. \& Limab, L.Y. (2010). Uptake and cytotoxicity of chitosan nanoparticles in human liver cells. Toxicology and $\begin{array}{lll}\text { Applied } & \text { Pharmacology. 249(2):148-157. }\end{array}$ https://doi.org/10.1016/j.taap.2010.08.029

Mahler, H., Pasi, A., Kramer, J. M., Schulte, P., Eng, G.\& Scoging, A. C., et al (1997). Fulminant liver failure in association with the emetic toxin of Bacillus cereus. New Engl. J. Med. 336, 1142-1148.DOI: 10.1056/NEJM199704173361604

Malmiri, H. J., Jahanian, M. A. G. \& Berenjian, A. (2012). Applications of chitosan nanoparticles as novel support in enzyme immobilization. American J $\begin{array}{lllll}\text { Biochem. } & \text { Biotechnol. } & 2012, & 8 & \text { (4), }\end{array}$ 219.DOI: https://doi.org/10.3844/ajbbsp.2012.203.219

Messelhäußer, U. \& Ehling-Schulz, M. (2018). Bacillus cereus-a multifaceted opportunistic pathogen. Curr. Clin. Microbiol. Rpt. 5, 120-125. doi: 10.1007/ s40588-018-0095-9

Mohamed, A. S., Mohamed, E. A. Alnakip, \& Salah, F. A. (2016). Occurrence of Bacillus cereus in raw milk and some dairy products in Egypt.Japanese J. Vet. Res.64 (Supplement 2): S95-102.

Mudagza, D. T. \& Buys, E. M. (2017). Diversity of Bacillus cereus strains in extended shelf life. Int Dairy J,73:144150.https://doi.org/10.1016/j.idairyj.2017.06.001

Nelson, J.A.\& Toru,t G.M. (1981). Judging Dairy Products, $4^{\text {th }}$ edition revised Westport, CT: The AVC, 1981.

Nguyen, T. V., Nguyen, T. H., Wang, S. L., VO, P. K.\& Nguyen, A. D. (2017) Preparation of chitosan nanoparticles by TPP ionic gelation combined with spray drying, and the antibacterial activity of chitosan nanoparticles and a chitosan nanoparticle-amoxicillin complex. Res. Chem. Inter. med. 43: 3527-3537. https://doi.org/10.1007/s11164-016-2428-8 
Ojagh, S. M., Rezaei, M., Razavi, S. H.\& Hosseini, S. M. H. (2010). Effect of chitosan coatings enriched with cinnamon oil on the quality of refrigerated rainbow trout. $\quad$ Food $\quad$ Chem.120(1): 198.DOI:10.1016/j.foodchem.2009.10.006

Organji, S. R., Abulreesh, H. H., Elbanna, K., Osman, G. \& Khider, M. (2015). Occurrence and characterization of toxigenic Bacillus cereus in food and infant feces. Asian Pac. J. Trop. Biomed., 5: 515-520.DOI: 10.1016/j.apjtb.2015.04.004 Papan, C., K. Fo"rster, R. Herterich, A. Schulze, S. Schubert, A. \& Flemmer, (2019). Identification and containment of a cluster of two Bacillus cereus infections in a neonatal intensive care unit.Can J Infect Dis Med Microbiol, 2019:1506583. https://doi.org/10.1155/2019/1506583

Prabaharan, M. (2008). Review paper: chitosan derivatives as promising materials for controlled drug delivery. J Biomater Appl. 23 (1):5-36 DOI: $10.1177 / 0885328208091562$

Qi, L., Xu, Z., Jiang, X., Li, Y.\& Wang, M. (2005). Cytotoxic activities of chitosan nanoparticles and copper-loaded nanoparticles. Bioorg. Med. Chem. Lett. 2005, 15, 1397-1399. doi: 10.1016/j.bmcl.2005.01.010.

Quesada, J., Sendra, E., Navarro, C.\& Sayas-Barberá, E. (2016). Antimicrobia active packaging including chitosan films with Thymus vulgaris L. essential oil for ready-to-eat meat. Foods 2016, 5, 57.doi: 10.3390/foods5030057

Rinaudo, M. (2006). Chitin and chitosan: properties and applications. ProgPolym Sci. 31:603-32.DOI: 10.1016/j.progpolymsci.2006.06.001

Raafat, D., Bargen, K. Haas, A. \& Sahl, H.-G.(2008). Insights into the Mode of Action of Chitosan as an Antibacterial Compound. Appl Environ Microbiol. 74(12): 3764-3773. doi: 10.1128/AEM.00453-08

Samapundo, S., Heyndrickx, M, Xhaferi, R.,\& Devlieghere, F. (2011). Incidence, diversity and toxin gene characteristics of Bacillus cereus group strains isolated from food products marketed in Belgium. Int. J. Food Microbiol.,150:34-41.doi: 10.1016/j.ijfoodmicro.2011.07.013.

Sharma, R. \& Rajput,Y. S. (2014). Rapid methods for assessing efficiency of heat treatment of milk. J Food Sci Technol. 2014 Jul, 51(7): 1416-1420. doi: 10.1007/s13197-012-0635-X

Silalahi, J., Situmorang, P., Patilaya, P. \& Ce Silalahi,Y. (2016). Antibacteria activity of chitosan and hydrolyzed coconut oil and their combination against Bacillus cereus and Escherichia coli. Asian J. Pharma. Clin. Res, 9: 6973.doi:10.22159/ajpcr.2016.v9i5.11768.

Sreekumar S., Goycoolea F. M., Moerschbacher B. M. \& Rivera-Rodriguez, G. R. (2018). Parameters influencing the size of chitosan-TPP nano- and microparticles. Sci. Rep. 8, 4695.https://doi.org/10.1038/s41598-018-23064-4

Sukmark T., Rachtanapun P. \& Rachtanapun C. (2011). Antimicrobial activity of oligomer and polymer chitosan from different sources against foodborne pathogenic bacteria. Kasetsart J. (Nat. Sci.), 45: 636- 643. https://li01.tcithaijo.org/index.php/anres/article/view/245342/167729

Suvarna, S. K., Layton, C. \& Bancroft, J. D. (2013). Bancroft's Theory and Practice of Histological Techniques. $7^{\text {th }}$ edn. Churchill Livingstone Elsevier.https://www.elsevier.com/books/bancrofts-theory-and-practice-ofhistological-techniques/unknown/978-0-7020-6886-7

Tallent, M. S., KoTewicz, M. K., Strain, A. E. \& Bennett, W. R. (2012) of Identification and Isolation . EfficientBacillus cereus Group. J. AOAC Inter. 95 (2).DOI: 10.5740/jaoacint.11-251

Tamara F. R., Chi L., Fwu-Long M. \& Yi-Cheng H. (2018). Antibacterial effects of chitosan/cationic peptide nanoparticles. Nanomaterials 2018, 8, 88, doi:10.3390/nano8020088

Tantala, J., Thongngam, M., Rachtanapun, P. \& Rachtanapun, C. (2012).Antimicrobial activity of chitosan and carboxymethyl chitosan from differences types and sources of chitosan. Italian J. Food Sci., XXIV, 97101.http://apps.webofknowledge.com/InboundService.do?

Tokura, S., Ueno, K., Miyazaki, S. \& Nishi, N. (1996). Molecular weight dependent antimicrobial activity by chitosan. In New Macromolecular Architecture and Functions. 1996, pp. 199-207. Springer Berlin Heidelberg.https://doi.org/10.1007/978-3-642-80289-8 21

Yang, Y., Gu, H., Yu, X., Zhan, L., Chen, J., Luo, Y., Zhang, Y., Zhang, Y., Lu, Y., Jiang, J.\& Mei, L. (2017). Genotypic heterogeneity of emetic toxin producing Bacillus cereus isolates from China. FEMS Microbiol Lett. 364:fnw237.doi 10.1093/femsle/fnw237.

Yeh, M-Y., Shih, Y-L., Chung, H-Y., Chou, J., Lu, H., Liu, C-H., Huang, W-W., Pang, S-F., Wu, L-Y. \& Chung, J-G. (2017). Chitosan promotes immune responses, ameliorating total mature white blood cell numbers, but increases glutamic oxaloacetic transaminase and glutamic pyruvic transaminase, and ameliorates lactate dehydrogenase levels in leukemia mice in vivo. Molecular Medicine Reports, 16: 2483-2490.https://doi.org/10.3892/mmr.2017.6923

Yokoyama, K., Ito, M., Agata, N., Isobe, M., Shibayama, K., Horii, T. \& Ohta, M. (1999). Pathological effect of synthetic cereulide, an emetic toxin of Bacillus cereus, is reversible in mice /FEMS Immunol. Med. Microbiol. 24, 115120.Federation of European Microbiological Societies. Published by Elsevier Science B.V. All rights reserved. PII: S 0928 - 8244 ( 99 ) 00017 - 60928$8244 / 99 / \$ 20.00$

Yu, P., Yu, S., Juan, W., Hui, G., Ying, Z., Xiyu, L., Junhui, Z., Shi, W., Qihui, G., Liang, X., Haiyan, Z., Rui, P., Tao, L., Zhang, J., Qingping, W. \& Yu,, D. (2019). Bacillus cereus Isolated From Vegetables in China: Incidence, Genetic
Diversity, Virulence Genes, and Antimicrobial Resistance. Frontiers in Microbiol., 10 (948). doi: 10.3389/fmicb.2019.00948

Yusman, D. A. (2006). Relationship between Antibacterial Activity of Chitosan and Surface Characteristics of Bacterial Cell Wall. Thesis, Departement of Chemistry, Faculty of Mathematics and Natural Sciences. Institut Pertanian Bogor, 2006. https://europepmc.org/article/med/15210068

Zaghloul, E. H. \& Ibrahim, H. A. (2019). Comparative study on antimicrobial activity of commercial and extracted chitin and chitosan from Marsupenaeus japonicus shells. Egyptian Journal of Aquatic Biology \& Fisheries Vol. 23(2): 291 - 302.DOI: 10.21608/EJABF.2019.31536

Zhang, Z., Feng, L., Xu, H., Liu, C., Shah, N.P. \& Wei, H. (2015). Detection of viable enterotoxin-producing Bacillus cereus and analysis of toxigenicity from ready to- eat foods and infant formula milk powder by multiplex PCR. J Dairy Sci. 99:1047-55.https://doi.org/10.3168/jds.2015-10147

Zhao, L., Shi, L., Zhang, Z., Chen, J., Shi, D., Yang, J. \& Tang, Z. (2011). Preparation and Application of Chitosan Nanoparticles and Nanofibers. Brazilian J. Chemical Engineering, 28: 353 - 362. https://doi.org/10.1590/S010466322011000300001

Zhao, S., Chen, J., Peng, F., Feng, H., Yao, W., Ali, A., Shuzhen, L., \&Yang, w. (2020). Prevalence, molecular characterization, and antibiotic susceptibility of Bacillus cereus isolated from dairy products in China. Journal of Dairy Science. https://doi.org/10.3168/jds.2019-17541.

Zheng, L. Y.\& Zhu, J. F. (2003). Study on antimicrobial activity of chitosan with different molecular weights. Carbohydrate Polymers. 54(4), $527-$ 530.https://doi.org/10.1016/j.carbpol.2003.07.009 